\title{
15 救急蘇生用気道チュープの開発
}

佐藤 暢 (鳥取大病院麻酔科), 和藤幸弘, 藤井 昭 (鳥取大病院手術部)

〔目的〕救急救命士制度が発足しても，法施行規則 に基づき, 厚生大臣の指定する気道確保の器具として 許されるものは，食道閉鎖式エアウェイ（EOA）と ラリンゲアルマスク（LM）のみであり，後で救急用 コンビチューブ（C B ）が食道内といら条件付きで使 用が許されたが，いずれも輸入品であり，かつ欠点が 多い，LMは麻醉用としては優れているが，無呼吸下 での緊急挿管では，適正な位置が決まり難く，気密性 にも劣るので, 食道からの逆流の多い救急蘇生用には 適さないＥOAは顔マスクを使うため深さの調節が できず，かつマスクの保持が困難である，C B 悢道 用には短かすぎ，心マッサージ中には適さない。

[万法]これらの短所を解消し, 盲目的に食道に必 ず入り，適当な食道下部閉鎖と口腔から咽頭上部での 気密性が確保でき，日本人の体格にあったディスポー ザブルで安価な蘇生用ェアウェイを開発したので報告 する.

〔結果】合併症の多い，技術的に困難な気管内㧌管
をしなくとも，容易に人工呼吸ができる便利な器具で あることを確かめた。

[考察】従来, 我々は気道内の換気, すなわち人工 呼吸を行らために，気管内插管を全面的に活用してき たが，今日，気管内挿管のできない救急救命士用とし て，食道閉鎖式エアウェイを顔マスクから咽頭バルー ン付きに改良してみたところ，以下の利点があること がわかった.

1）食道下部閉鎖用カフと咽頭内バルーンとの距離 を変觉るだけで，大小の体格に合う4 サイズを作るこ とができる。

2) チューブの形状, 材質と先端の形を工夫して, 容易浪食内に挿管できる.

3) カフとバルーンの内压を調整することによっ て, 約 $40 \mathrm{cmH}_{2} \mathrm{O}$ までの陽圧換気ができ, かつ固定 は良好で，加生による動摇はない。

4) 侵襲が少なく, 気道確保に有用である.

\section{3 種類の麻酔ガスモニタの比較検討}

平井幸彦（聖マリア病院臨床工学室）, 高松 純（聖マリア病院麻酔科）

[目的]今回, MERA 社の麻醉ガスモニタ（以下 M）を使用する機会を得たので DATEX 社の ULTIMA (以下U) 及び CAPNOMAC (以下C) と比 較検討してみた.

[方法]気化器 (OHMEDA 社製 SEBOTEC 4) に拈ける $1.0 \%, 2.0 \%, 3.0 \%, 4.0 \%, 5.0 \%$ と測定 項目を変化したとき，打の扔のについて酸素流量を $2 ， 4,6 \mathrm{~L} / \mathrm{min}$ としたときのモ二タの表示值を, 記録 した. 再現性を見る為に 4 回繰り返した.

[結果] $1.0 \%, 2.0 \%, 3.0 \%$ のとき酸素流量を変
化しても M，U，Cともに特に差異は見られなかっ た.

4.0\%，5.0\%のとさ酸素流量を变化してもM，Uは 特に羑異はなかったが，Cは $4.0 \% ， 2 \mathrm{~L} / \mathrm{min}$ のとき $3.85 \pm 0.15$ であったが, 酸素流量を $4,6 \mathrm{~L} / \mathrm{min}$ と変

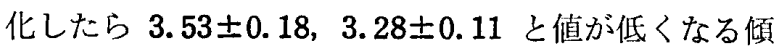
向が見られた。 また，5.0\% でも同様な傾向が見られ た。

[考察】 以上より，MERA 社のモニタは臨床で使 用するのに十分有用であると招もわれる. 